\title{
Field Evaluation of Biological Control of Fire Blight in the Eastern United States
}

\author{
George W. Sundin, Department of Plant Pathology, Michigan State University, East Lansing, MI 48824; Nicole A. \\ Werner, Department of Plant Pathology, New York Agricultural Experiment Station, Geneva, NY 14456; Keith S. \\ Yoder, Virginia Polytechnic Institute and State University Agricultural Research and Extension Center, Winchester, \\ VA 22602; Herb S. Aldwinckle, Department of Plant Pathology, New York Agricultural Experiment Station, Ge- \\ neva, NY 14456
}

\begin{abstract}
Sundin, G. W., Werner, N. A., Yoder, K. S., and Aldwinckle, H. S. 2009. Field evaluation of biological control of fire blight in the eastern United States. Plant Dis. 93:386-394.

The bacterial antagonists Pseudomonas fluorescens A506, Pantoea agglomerans C9-1, and Pantoea agglomerans E325 and preparations of Bacillus subtilis QST 713 containing bacterial endospores and lipopeptide metabolites were evaluated for efficacy in controlling fire blight in Michigan, New York, and Virginia. When examined individually, the biological control materials were not consistently effective in reducing blossom infection. The average reduction in blossom infection observed in experiments conducted between 2001 and 2007 was variable and ranged from 9.1 to $36.1 \%$, while control with streptomycin was consistent and ranged from 59.0 to $67.3 \%$. Incidence of blossom colonization by the bacterial antagonists was inconsistent, and $<60 \%$ of stigmata had the antagonists present in 12 of 25 experiments. Consistent control of blossom infection was observed when the biological control materials were integrated into programs with streptomycin, resulting in a reduction of the number of streptomycin applications needed to yield similar levels of control. Our results indicate that the prospects for biological control of fire blight in the eastern United States are currently not high due to the variability in efficacy of existing biological control options.
\end{abstract}

Fire blight, caused by the bacterium $E r$ winia amylovora, is a major disease of apple and pear in most areas of the world where pome fruit are grown. The onset of disease each year is initiated by epiphytic E. amylovora cells; under conducive environmental conditions, these cells multiply rapidly on the stigmatic surfaces of flowers, and can be readily disseminated by pollinating insects $(27,33)$. Subsequent wetting events through rain or dew facilitate bacterial migration to the hypanthium where infection occurs via nectarthodes (32,36). Infection of flowers enables the pathogen to spread internally within the host, and pathogen cells can also emerge from symptomatic flowers as bacterial ooze that can serve as inoculum for additional shoot infection.

Thus, the flower is a site of seasonal amplification of E. amylovora populations, and since the pathogen is on the surface of stigmata, the flower is also the site where

Corresponding author: G. W. Sundin

E-mail: sundin@msu.edu

Current address of N. A. Werner: Department of Environmental and Forest Biology, SUNY College of Environmental Science and Forestry, Syracuse, NY 13210.

Accepted for publication 30 December 2008.

doi:10.1094/PDIS-93-4-0386

() 2009 The American Phytopathological Society the pathogen can best be targeted by the use of bactericides. The antibiotic streptomycin is currently the most effective compound available to growers for limiting populations of the fire blight bacterium on flowers. Unfortunately, due to the reliance of the apple and pear industries on streptomycin for fire blight control, streptomycin resistance has developed in E. amylovora populations in production areas including the Pacific Northwest, California, and Michigan $(12,14,15)$. The availability of alternative antibiotics for fire blight control is limited and has driven investigations into the effectiveness of microbial antagonists in suppressing blossom blight (5).

Commercial formulations of three bacterial antagonists are currently available in the United States for blossom blight control. These include Pseudomonas fluorescens A506 (active ingredient of BlightBan A506 [Nufarm Americas, Burr Ridge, IL]), which was originally selected as an organism that could inhibit ice nucleation-active $P$. syringae strains on corn leaves and was later shown to reduce the occurrence of blossom blight in studies in California (11). The other commercialized bacteria are both strains of Pantoea agglomerans: strain C9-1 (an ingredient in BlightBan A506 + C9-1 [Nufarm Americas]) produces the antibiotics herbicolin $\mathrm{O}$ and $\mathrm{I}$, with antibiotic activity against E. amylovora (4); and strain E325 (active ingredient of Bloomtime Biological FD Biopesticide
[Northwest Agricultural Products, Wenatchee, WA]) was selected from a large collection of apple blossom epiphytes for its ability to suppress fire blight infection $(21,22)$. Many other bacterial antagonists have been isolated and examined in vitro for inhibitory activity against $E$. amylovora (16), and some have been evaluated in the field for control of blossom blight. These bacteria include additional strains of species known to be effective in the biological control of fire blight, including Pantoea agglomerans Eh252, Eh1087, and P10c $(2,28,31,34)$, and Pseudomonas fluorescens EPS62e (20). Separate strategies involve the use of Bacillus subtilis strains QST713 (active ingredient of Serenade [AgraQuest, Davis, CA]) and BD170 (active ingredient of BioPro [Biosystem GmbH, Konstanz, Germany]) (2). The mode of action of Serenade originates from lipopeptides produced by $B$. subtilis QST713 that exhibit antimicrobial activity against a wide range of pathogens. The formulations of this product contain both the active lipopeptides and $B$. subtilis endospores.

For successful biological control of blossom blight, bacterial antagonists are formulated at a concentration of $1 \times 10^{10}$ to $1 \times 10^{11} \mathrm{CFU} / \mathrm{g}$ and must be applied early enough during the bloom period to allow epiphytic populations of the antagonist to reach levels high enough to preemptively exclude the establishment of the pathogen on stigmata. Labels of the registered products suggest applications at early bloom (15 to $20 \%$ bloom) and late bloom (full bloom to petal fall). Once established, temperatures favorable for bacterial growth $\left(>15^{\circ} \mathrm{C}\right)$ along with dynamic pollinator activity will facilitate the spread of the antagonists and ensure the colonization of stigmatic surfaces, thereby increasing their efficacy (8).

The success of bacterial biological control agents in the western United States has been erratic. For example, treatments with BlightBan A506 and BlightBan C9-1 have been shown to reduce the incidence of blossom blight by 40 to $80 \%$ in the Pacific Northwest in multiple experiments conducted over a 6-year period (5). Integration of biological control with antibiotic treatments has also been utilized and represents a promising approach to reduce the number of applications of streptomycin. The 
potential of bacterial biological control agents such as BlightBan A506 for fire blight control in the eastern United States has been evaluated more recently than in the West. The greater rainfall and humidity in eastern apple orchard locations compared to their western counterparts commonly provides conducive conditions for the development of fire blight epidemics. Environmental conditions, coupled with the existing streptomycin resistance problem in Michigan (13), and the potential for streptomycin resistance development in other states including New York (25), signifies the need to explore alternative methods for fire blight control.

Here we summarize biological control studies that were conducted in Michigan, New York, and Virginia between 2001 and 2007. We present fire blight control efficacy data as well as incidence of colonization of stigmata by biological control organisms applied in orchards.

\section{MATERIALS AND METHODS}

Bacterial strains. Spontaneous rifampicin-resistant $\left(\mathrm{Rif}^{\mathrm{R}}\right)$ mutants of E. amylovora Ea110 and Ea273 were used as pathogen inoculum in all Michigan and New York field experiments, respectively. Strain Ea110 was isolated from a diseased apple tree in Michigan (24), and Ea273 (ATCC 49946) was isolated from a diseased apple tree in New York. The field inoculations in Virginia were initiated with E. amylovora AFRS581, which was isolated from a diseased apple tree in West Virginia. Pathogen strains in Michigan and New York were stored in $15 \%$ glycerol at $-80^{\circ} \mathrm{C}$ prior to use. Virginia strain AFRS581 was stored at $4^{\circ} \mathrm{C}$ under phosphate buffer on nutrient agar slants.

The antagonistic bacterium Pseudomonas fluorescens strain A506 was isolated from pear in California by S. Lindow and is currently registered in the United States as "BlightBan A506" by Nufarm Americas. Pantoea agglomerans strain C9-1 was isolated from apple in Michigan by $\mathrm{C}$. Ishimaru (4) and is manufactured as "BlightBan C9-1" by Nufarm Americas. In addition, a combined formulation of Pseudomonas fluorescens strain A506 and Pantoea agglomerans strain C9-1 is manufactured as "BlightBan A506 + C9-1" by Nufarm Americas. However, neither BlightBan C9-1 nor BlightBan A506 + C91 is currently registered in the United States. Pantoea agglomerans strain E325 was isolated from apple by L. Pusey in Washington $(21,22)$ and is registered in the United States and Canada as "Bloomtime Biological" by Northwest Agricultural Products, Pasco, WA. All of these organisms are resistant to rifampicin and streptomycin, and commercially formulated products consisting of the microbial antagonists were stored at $-20^{\circ} \mathrm{C}$ until use.

Efficacy experiment plot design. Field experiments to test the efficacy of various biological control agents were conducted in blocks of about 50 to 100 apple trees of various cultivars. Biological control treatments were applied to trees prior to, and sometimes after, inoculation with a virulent E. amylovora strain. Following a sufficient duration to allow blossom blight infection to occur (usually approximately 28 days), trees were rated for the incidence of blossom blight symptoms.

Experiments in Michigan in 2004 and 2005 were conducted in East Lansing on 'Jonathan' grafted on MM.106 rootstock. In 2006 and 2007, 'Jonathan' apple trees on M.9 rootstock were used. Treatments were arranged in a randomized complete block design with five single-tree replicates per treatment in 2004 and 2005 and four single-tree replicates per treatment in 2006 and 2007. Experiments in New York were conducted in Geneva using 'Idared' on M.7 rootstock. Treatments were arranged in a randomized complete block design with five single-tree replicates per treatment. Experiments in Virginia were conducted at the Virginia Tech Agricultural Research and Extension Center in Winchester using 'Rome' on MM.106 rootstock in 2002 and 2003 and 'Idared' on MM.111 rootstock in 2005 and 2006. Treatments were arranged in a randomized complete block design with four singletree replicates per treatment.

Weather conditions. In Michigan, weather data were recorded by a weather station maintained by the Michigan Automated Weather Network located $1 \mathrm{~km}$ from the study site. In New York, temperature and rainfall were recorded by a weather station maintained by Cornell University Field Research Unit located within $1 \mathrm{~km}$ of the study site. In Virginia, environmental conditions were recorded by a weather station located within $1 \mathrm{~km}$ of the study site.

Inoculum preparation and pathogen inoculation. Bacterial cultures of E. amylovora cells for field inoculations were grown in Luria Bertani broth at 27 to $28^{\circ} \mathrm{C}$ to late log-early stationary phase or on nutrient yeast dextrose agar at 27 to $28^{\circ} \mathrm{C}$ for up to $24 \mathrm{~h}$. Cell suspensions were adjusted turbidimetrically to the desired cell density $\left(10^{6}\right.$ to $10^{7}$ cells $\left./ \mathrm{ml}\right)$ in $0.5 \times$ sterile phosphate buffered saline and kept on ice during transfer to the field and prior to inoculations. In Michigan, apple trees were inoculated on 4 May 2004, 12 May 2005, 3 May 2006, and 6 May 2007 by spraying blossom clusters to runoff around the perimeter of each tree with a suspension of E. amylovora Ea110. Cell densities were $10^{6} \mathrm{CFU} / \mathrm{ml}$ in 2004, 2005, and 2007 and $10^{7} \mathrm{CFU} / \mathrm{ml}$ in 2006. An 11.4-liter pump mist sprayer was used for the inoculations. Inoculation occurred at full bloom during the evening to ensure conditions favorable for bacterial survival. In New York, apple trees were inoculated at full bloom on the mornings of 8 May 2001, 7 May 2002, 18
May 2003, 13 May 2004, 17 May 2005, and 10 May 2006 with a suspension of $E$. amylovora Ea273 at $10^{7} \mathrm{CFU} / \mathrm{ml}$ applied to runoff using a backpack sprayer. In Virginia, four tagged branches per tree, each with 30 to 50 blossom clusters, were inoculated by spraying with a bacterial suspension of E. amylovora AFRS581 at $10^{6}$ $\mathrm{CFU} / \mathrm{ml}$ until flowers were wet. Inoculation occurred in the evening the day after treatment with biological controls or streptomycin at full bloom on 18 April 2002, 1 day after each of the first two treatment applications on 21 April and 29 April 2005, and 1 day after each treatment application on 13, 19, and 24 April 2006.

Treatment applications. All field experiments included a control treatment (nontreated, pathogen-inoculated trees) and a standard treatment (Agri-Mycin [17\% streptomycin sulfate; Nufarm Americas], pathogen-inoculated trees). Treatments with formulated biocontrol agents were applied with a handgun sprayer at $24.6 \mathrm{~kg} / \mathrm{cm}^{2}$ and 2,800 liters of water per hectare, $14.1 \mathrm{~kg} / \mathrm{cm}^{2}$ and 2,330 liters of water per hectare, and $31.6 \mathrm{~kg} / \mathrm{cm}^{2}$ and 2,800 liters of water per hectare, in Michigan, New York, and Virginia, respectively. Application timings for the biocontrol product (bacterial antagonists) formulations were typically early in the bloom period (e.g., $1 \%, 20$ to $30 \%$, and 70 to $80 \%$ bloom) in an attempt to maximize colonization prior to and at full bloom. Application timings for Serenade formulations and Agri-Mycin were generally at full bloom. The adjuvant Biotune (AgraQuest) and the surfactant Break-Thru (J.R. Simplot Co., Boise, ID) were used in some cases in an attempt to increase penetration of chemical or biological control products into flower tissue. Experiments were also performed in which the biological control materials were utilized in integrated treatments that included applications of Agri-Mycin. These integrated treatments involved a reduction in the total number of AgriMycin applications compared to the standard treatment.

Disease assessment. In Michigan, blossom blight was evaluated on 4 June 2004, 7 June 2005, 2 June 2006, and 30 May 2007 by counting the total number of diseased blossom clusters (2004) or the number of diseased blossom clusters in a sample of 210 clusters (2005 to 2007). In New York, blossom blight was evaluated by counting the number of diseased or healthy clusters out of a maximum of 200 clusters per tree on 5 June 2001, 4 June 2002, 10 June 2003, 7 June 2004, 13 June 2005, and 2 June 2006. In Virginia, on 16 May 2002, diseased and healthy flower clusters on the inoculated limbs were counted after symptoms had progressed beyond individual flowers. In the 2005 and 2006 trials, total blossom clusters on tagged branches were counted 28 April and 10 April, respectively. Diseased blossom clusters on those 
branches were then counted on 19 May 2005 and 29 April 2006. Percentage of clusters infected was based on counts of total clusters present on inoculated branches at the time of inoculation. In all locations, a cluster was considered infected if one or more flowers exhibited fire blight symptoms.

Incidence of colonization by bacterial antagonists. In Michigan, incidence of colonization of flowers by the bacterial antagonists was assessed on 12 May 2005 and 5 May 2006, $48 \mathrm{~h}$ after the last applications of BlightBan A506 or BlightBan C9-1 and prior to inoculation with E. amylovora. Incidence of colonization was assessed by imprinting stigmata ( 21 per tree) that were arbitrarily selected from around the entire tree directly onto King's medium $\mathrm{B}$ (10) amended with $100 \mu \mathrm{g} \mathrm{ml}^{-1}$ rifampicin (KBr). In New York, on 15 May 2005 and 9 May 2006, 32 and 24 flowers per tree, respectively, were collected and imprinted onto $\mathrm{KBr}$ (2005) or imprinted without removal from the tree (2006) onto Pseudomonas agar F (Sigma-Aldrich, St. Louis, MO) amended with $100 \mu \mathrm{g} \mathrm{ml}^{-1}$ rifampicin. In both cases, flower imprinting was done $24 \mathrm{~h}$ after the last application of antagonists and prior to inoculation with E. amylovora. In 2006, treatments of Bloomtime Biological E325 were reduced to four replicates; therefore, a total of 96 flowers were imprinted. In Virginia, on 5 to 6 May 2005 and 26 to 27 April 2006, 48 $\mathrm{h}$ after the final application at late bloom, 18 flowers per inoculated and noninoculated side of each tree were sampled for presence of the antagonists by stigma imprinting on $\mathrm{KBr}$. At all locations, gloved hands were disinfected with $70 \%$ ethanol after the total flowers were collected or imprinted from one tree before moving to the next tree to reduce cross-contamination of the samples. Plates were incubated at 22 to $24^{\circ} \mathrm{C}$ for 24 to $48 \mathrm{~h}$, and bacterial antagonists were identified according to fluorescence and colony morphology. Incidence data were reported as a percentage ([number of positives/total number of flowers imprinted] $\times 100$ ).

Statistical methods. Statistical analyses of data collected in Michigan were done using a one-way analysis of variance, and mean separation was accomplished using Fisher's protected least significant difference test $(P \leq 0.05)$. Data collected in New York and Virginia were analyzed using a one-way analysis of variance, and mean separation was accomplished using WallerDuncan $k$-ratio $t$ test $(P \leq 0.05)$.

\section{RESULTS}

Weather conditions. A summary of temperature, average relative humidity, and total rainfall during the bloom period at each site is presented in Table 1. The lowest minimum temperature recorded $24 \mathrm{~h}$ following application of bacterial antagonists was $\leq 7.3^{\circ} \mathrm{C}$ in 9 of 10 experiments, and the maximum temperature following application never exceeded $28.9^{\circ} \mathrm{C}$ (Table 1 ). In contrast, the lowest minimum temperature recorded $24 \mathrm{~h}$ following pathogen inoculation was $\geq 12.8^{\circ} \mathrm{C}$ in 5 of 10 experiments (Table 1). The most consistent rainfall during the bloom period occurred at the Virginia site with relatively dry conditions occurring in New York (Table 1).

Efficacy of bacterial antagonists for blossom blight control. BlightBan A506. A total of 14 experiments were conducted to evaluate the efficacy of BlightBan A506 on E. amylovora-inoculated apple trees. The most common experimental treatment consisted of two applications, one at 20 to $30 \%$ and another at 70 to $80 \%$ bloom. This application strategy was ineffective in four of six experiments, resulting in blossom blight levels that exceeded that of the nontreated control in three experiments (Table 2). This application regimen provided significant disease control only in 2005 in Michigan; however, the overall level of disease in 2005 in nontreated control trees was $10.1 \%$, a level which is likely too low from which to draw meaningful comparisons. In Virginia, experi- ments utilizing later application timings ( $100 \%$ bloom and $100 \%$ bloom +4 days $)$ or a combination of early and later applications (1 to $5 \%$ and $100 \%$ bloom and petal fall) did not result in levels of control that were significantly different from the nontreated control (Table 2). In three experiments, the surfactant Break-Thru was included in a BlightBan A506 application at 1 to $5 \%$ bloom in an attempt to enable early penetration of the $P$. fluorescens bacterium into unopen flowers. This strategy was also ineffective, with significant disease control observed only in the 2005 experiment in Michigan (Table 2). In summary, BlightBan A506 was not effective in reducing blossom blight in experiments conducted in Michigan, New York, and Virginia from 2002 through 2006. The incidence of blossom blight in BlightBan A506-treated trees was as high as $79.3 \%$, and the incidence of blossom blight was not significantly different from a nontreated control in 12 of the 15 experimental treatments (Table 2). In contrast, the frequency of blossom blight was reduced significantly compared to a nontreated control in the Agri-Mycin standard treatment in 14 of the 15 experimental treatments (Table 2). Overall, the average percent reduction in blossom blight by BlightBan A506 observed was $9.1 \%$ in the 11 studies that did not include Break-Thru, $12.5 \%$ in all 14 studies, and $-6.0 \%$ in 11 studies if the 2005 results from Michigan were omitted from the calculations. In contrast, the average percent reduction in blossom blight in the Agri-Mycin treatments was $61.0 \%$.

BlightBan C9-1. Nine experiments were conducted to evaluate the efficacy of BlightBan C9-1 on E. amylovora-inoculated apple trees. BlightBan C9-1 was more efficacious than BlightBan A506, as significant reductions in blossom blight were observed in four experiments (Table 3). Most prominently, the level of control observed in 2004 in New York was not significantly different from that of the

Table 1. Summary of weather conditions at each location during the bloom period when antagonistic bacterial treatments and pathogen inoculations were applied

\begin{tabular}{|c|c|c|c|c|c|c|c|c|c|}
\hline \multirow[b]{2}{*}{ Location } & \multirow[b]{2}{*}{ Year } & \multirow{2}{*}{$\begin{array}{l}\text { Min daily } \\
\operatorname{temp}^{\mathrm{a}}\left({ }^{\circ} \mathrm{C}\right)\end{array}$} & \multirow{2}{*}{$\begin{array}{l}\text { Max daily } \\
\operatorname{temp}{ }^{a}\left({ }^{\circ} \mathbf{C}\right)\end{array}$} & \multicolumn{2}{|c|}{$\begin{array}{c}\text { Temp } 24 \text { h after } \\
\text { inoculation }{ }^{\mathrm{b}}\left({ }^{\circ} \mathrm{C}\right)\end{array}$} & \multicolumn{2}{|c|}{$\begin{array}{l}\text { Temp } 24 \text { h after } \\
\text { treatment }^{\mathrm{b}}\left({ }^{\circ} \mathrm{C}\right)\end{array}$} & \multirow{2}{*}{$\begin{array}{c}\text { Average daily } \\
\text { RH (\%) }\end{array}$} & \multirow{2}{*}{$\begin{array}{c}\text { Total rainfall } \\
\text { (cm) }\end{array}$} \\
\hline & & & & Min & Max & Min & $\operatorname{Max}$ & & \\
\hline \multirow[t]{4}{*}{ Michigan $^{c}$} & 2004 & $-1.8-14.4$ & $6.8-26.0$ & -2.1 & 8.6 & -1.0 & 21.5 & 69.7 & 3.2 \\
\hline & 2005 & $2.6-16.9$ & $12.6-26.5$ & 12.8 & 17.7 & 3.4 & 25.7 & 62.0 & 11.0 \\
\hline & 2006 & $2.9-15.1$ & $14.1-23.6$ & 15.1 & 18.7 & 2.9 & 23.6 & 70.1 & $<1.0$ \\
\hline & 2007 & $4.6-13.9$ & $16.8-22.6$ & 4.6 & 20.5 & 4.6 & 22.6 & 43.1 & 0.0 \\
\hline \multirow[t]{3}{*}{ New York ${ }^{\mathrm{d}}$} & 2004 & $7.7-19.1$ & $16.7-29.9$ & 19.1 & 29.9 & 12.7 & 28.4 & 71.3 & 1.0 \\
\hline & 2005 & $-1.1-11.3$ & $9.7-28.7$ & 4.4 & 12.9 & -1.1 & 28.5 & 63.3 & 1.0 \\
\hline & 2006 & $2.0-13.0$ & $10.7-24.8$ & 15.3 & 23.4 & 5.9 & 24.4 & 68.5 & 2.7 \\
\hline \multirow[t]{3}{*}{ Virginia $^{e}$} & 2002 & $-1.0-16.7$ & $11.6-28.9$ & 16.0 & 18.7 & 2.3 & 28.9 & 69.0 & 6.8 \\
\hline & 2005 & $0.3-12.5$ & $7.9-28.4$ & 6.8 & 19.8 & 7.3 & 12.5 & 62.2 & 2.6 \\
\hline & 2006 & $3.4-14.7$ & $13.8-26.7$ & 5.3 & 25.3 & 5.9 & 25.1 & 58.2 & 4.7 \\
\hline
\end{tabular}

a Temperature ranges include dates from first treatment through $24 \mathrm{~h}$ after last treatment (refer to text for specific dates).

b Absolute minimum or maximum temperature is reported if there were multiple inoculations or treatments during a particular year.

c Weather station maintained by Michigan Automated Weather Network located $1 \mathrm{~km}$ from study site.

d Weather station maintained by Cornell University Field Research Unit located within $1 \mathrm{~km}$ of study site.

e Weather station maintained by Virginia Tech University located within $1 \mathrm{~km}$ of study site. 
Agri-Mycin standard (Table 3). The overall mean frequency of blossom blight symptoms (excluding the 2005 data from Michigan) in experiments where both treatments were used was 40.1 and $48.4 \%$ in C9-1 and A506 experimental treatments, respectively. With C9-1, there was no correlation between the number of applications and level of control, as significant reductions in blossom blight were observed in an equal number of experiments incorporating two or three applications (Table 3). In summary, C9-1 gave significant control (mean $33.1 \%$ ) compared to nontreated trees in four of nine experiments. Agri-Mycin gave $63.3 \%$ control and a significant result in eight of those eight experiments. The use of Break-Thru in a 1 to $5 \%$ bloom application was only evaluated in one experiment, and a significant reduction in blossom blight was observed (Table 3).

BlightBan C9-1 + A506. A combined formulation of BlightBan containing both Pantoea agglomerans $\mathrm{C} 9-1$ and Pseudomonas fluorescens A506 was evaluated in nine experiments. The overall mean frequency of blossom blight (excluding the 2005 data from Michigan) was $45.3 \%$, which was greater than that observed for C9-1 alone from the same experiments. A significant reduction in blossom blight frequency compared to the nontreated control was observed in three of nine ex- perimental treatments (Table 3), and the level of control observed in 2006 in Michigan was not significantly different from that of the Agri-Mycin standard (Table 3). In contrast with BlightBan C9-1, the addition of Break-Thru to the 1 to $5 \%$ bloom application of BlightBan C9-1 + A506 did not result in increased blossom blight control (Table 3). Overall, mean reduction in blossom blight by BlightBan C9-1 + A506 was 26.5\%; Agri-Mycin gave $60.4 \%$ suppression in those tests.

Bloomtime Biological E325. Seven experiments with eight total treatments were conducted to evaluate the efficacy of Bloomtime Biological E325 on E. amylovora-inoculated apple trees. Efficacy results with Bloomtime Biological were similar to those with BlightBan C9-1, as we observed a significant reduction in the frequency of blossom blight in three experiments and an increased incidence of disease in one experiment (Table 4). The overall mean frequency of blossom blight (excluding the 2005 data from Michigan) in comparable experiments where all biological antagonist treatments were utilized was $40.1 \%$, which was identical to that of BlightBan C9-1. Greater than 50\% control was observed in only two of the eight experiments. As with the other bacterial antagonists, the level of control with AgriMycin alone $(67.3 \%)$ was superior to that of Bloomtime Biological (28.5\%, Table 4).
Efficacy of Serenade for blossom blight control. Eleven experiments were conducted to evaluate the efficacy of Serenade on E. amylovora-inoculated apple trees. Application timings in most of the experiments included 70 to $80 \%$ and $100 \%$ bloom. Five different formulations were used between 2001 and 2006, with the MAX formulation used in the five most recent experiments. Serenade provided effective disease control in most of the experiments, with the frequency of blossom blight reduced significantly compared to a nontreated control in eight of 11 experiments (Table 5). Mean average percent reduction of blossom blight by the Serenade formulations and AgriMycin was 36.1 and $65.9 \%$, respectively (Table 5).

Incidence of colonization of apple flowers by bacterial antagonists. The biological control ability of BlightBan A506, C9-1, and Bloomtime Biological E325 is thought to be directly correlated with the ability of these bacteria to preemptively colonize flowers and reduce blossom infection by E. amylovora through competitive exclusion or antibiosis (5). Therefore, we assessed the frequency of colonization by bacterial antagonists in experiments conducted in 2005 and 2006 using a stigma imprint technique. The incidence of Pseudomonas fluorescens A506 ranged from 26.4 to $96.2 \%$ (Table

Table 2. Efficacy of biological control agent Pseudomonas fluorescens A506 (BlightBan A506) in reducing the frequency of the blossom blight phase of fire blight at three locations in the eastern United States from 2002 through $2006^{\mathrm{a}}$

\begin{tabular}{|c|c|c|c|c|c|c|c|c|}
\hline \multirow{2}{*}{$\begin{array}{l}\text { Location } \\
\text { (year and cell density) }\end{array}$} & \multicolumn{5}{|c|}{ Application timing ${ }^{\mathbf{b}}$} & \multirow{2}{*}{$\begin{array}{c}\text { \% Blossom } \\
\text { blight }^{c}\end{array}$} & \multicolumn{2}{|c|}{$\%$ Reduction in blossom blight $^{\mathrm{d}}$} \\
\hline & $1-5 \%$ & $20-30 \%$ & $70-80 \%$ & $100 \%$ & $\mathbf{P F}$ & & A506 & Agri-Mycin $^{e}$ \\
\hline Winchester, VA (2002) & $\ldots$ & $\ldots$ & $\ldots$ & $\mathrm{X}$ & $\mathrm{f}$ & 74.4 & 2.7 & $60.0^{*}$ \\
\hline E. Lansing, MI (2004) & $\ldots$ & $\mathrm{X}$ & $\mathrm{X}$ & $\ldots$ & $\ldots$ & $122.8^{\mathrm{g}}$ & -42.8 & $96.3^{*}$ \\
\hline Geneva, NY (2004) & $\ldots$ & $\mathrm{X}$ & $\mathrm{X}$ & $\mathrm{X}$ & $\ldots$ & 79.3 & 8.4 & $44.1 *$ \\
\hline \multicolumn{9}{|l|}{ E. Lansing, MI (2005) } \\
\hline$\left(1 \times 10^{10} \mathrm{CFU} / \mathrm{g}\right)$ & 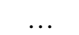 & $\mathrm{X}$ & $\mathrm{X}$ & $\ldots$ & $\ldots$ & 2.6 & $74.2 *$ & $70.3^{*}$ \\
\hline$\left(1 \times 10^{10} \mathrm{CFU} / \mathrm{g}\right)$ & $\mathrm{X}^{\mathrm{h}}$ & $\mathrm{X}$ & $X$ & $\ldots$ & $\ldots$ & 1.4 & $86.2^{*}$ & $70.3^{*}$ \\
\hline$\left(1 \times 10^{11} \mathrm{CFU} / \mathrm{g}\right)$ & $\ldots$ & $\mathrm{X}$ & $\mathrm{X}$ & $\ldots$ & $\ldots$ & 1.9 & $81.2^{*}$ & $70.3^{*}$ \\
\hline \multicolumn{9}{|l|}{ Geneva, NY (2005) } \\
\hline$\left(1 \times 10^{10} \mathrm{CFU} / \mathrm{g}\right)$ & & $X$ & $X$ & $\ldots$ & $\ldots$ & 39.5 & -20.4 & $80.2 *$ \\
\hline$\left(1 \times 10^{10} \mathrm{CFU} / \mathrm{g}\right)$ & $\mathrm{X}^{\mathrm{h}}$ & $\mathrm{X}$ & $\mathrm{X}$ & $\ldots$ & $\ldots$ & 37.9 & -15.5 & $80.2 *$ \\
\hline$\left(1 \times 10^{11} \mathrm{CFU} / \mathrm{g}\right)$ & $\ldots$ & $\mathrm{X}$ & $\mathrm{X}$ & $\ldots$ & $\ldots$ & 46.8 & -42.7 & $80.2 *$ \\
\hline \multicolumn{9}{|l|}{ Winchester, VA (2005) } \\
\hline$\left(1 \times 10^{10} \mathrm{CFU} / \mathrm{g}\right)$ & $\mathrm{X}$ & $\ldots$ & $\ldots$ & $\mathrm{X}$ & $X$ & 24.2 & 24.1 & $46.7 *$ \\
\hline$\left(1 \times 10^{11} \mathrm{CFU} / \mathrm{g}\right)$ & $\ldots$ & $\ldots$ & $\ldots$ & $\mathrm{X}$ & $\mathrm{X}$ & 30.8 & 3.4 & $46.7 *$ \\
\hline \multicolumn{9}{|l|}{ Geneva, NY (2006) } \\
\hline$\left(5 \times 10^{10} \mathrm{CFU} / \mathrm{g}\right)$ & & $\mathrm{X}$ & $\mathrm{X}$ & $\ldots$ & $\ldots$ & 74.6 & 3.0 & $44.7 *$ \\
\hline$\left(5 \times 10^{10} \mathrm{CFU} / \mathrm{g}\right)$ & $\mathrm{X}^{\mathrm{h}}$ & $\mathrm{X}$ & $\mathrm{X}$ & $\ldots$ & $\ldots$ & 73.8 & 4.0 & $44.7 *$ \\
\hline \multirow[t]{2}{*}{ Winchester, VA (2006) } & $\mathrm{X}$ & $\cdots$ & $\cdots$ & $\mathrm{X}$ & $\mathrm{X}$ & 29.1 & 9.3 & 19.9 \\
\hline & & & & & & MEAN: & 12.5 & 61.0 \\
\hline
\end{tabular}

a Trees were inoculated with Erwinia amylovora strains Ea110 at $10^{6} \mathrm{CFU} / \mathrm{ml}$ (MI), Ea273 at $10^{7} \mathrm{CFU} / \mathrm{ml}(\mathrm{NY})$, or AFRS581 at $10^{6} \mathrm{CFU} / \mathrm{ml}$ (VA). Inoculations were typically made at $100 \%$ bloom. BlightBan A506 was applied at a rate of $0.2 \mathrm{~g} /$ liter in MI, $0.7 \mathrm{~g} / \mathrm{liter}$ in NY, $0.7 \mathrm{~g} / \mathrm{liter}$ in VA (2002), and 0.5 $\mathrm{g} /$ liter in VA (2005 and 2006). Cell suspension density was $1 \times 10^{10} \mathrm{CFU} / \mathrm{g}$ unless otherwise noted.

${ }^{b}$ Materials were applied to trees when the indicated percentage of flowers were open or at petal fall (PF).

${ }^{c}$ Mean percentage of blossom clusters infected.

${ }^{\mathrm{d}}$ Comparison of frequency of blossom blight in biological control treatments versus frequencies in nontreated control treatments. Positive numbers denote the frequency of disease control. Asterisks indicate the respective treatment result was significantly different $(P \leq 0.05)$ from the nontreated control.

${ }^{\mathrm{e}}$ The Agri-Mycin standard was used at a rate of $100 \mu \mathrm{g} / \mathrm{ml}$ and applied 1 day prior to and 1 day following inoculation in Michigan and New York. In Virginia, Agri-Mycin was applied at $100 \mu \mathrm{g} / \mathrm{ml}$ the day of inoculation in 2002 and at $50 \mu \mathrm{g} / \mathrm{ml}$ the day before inoculation in 2005 and 2006.

${ }^{f}$ In 2002, BlightBan A506 and Agri-Mycin treatments were applied at 100\% bloom and 4 days later only in the Winchester, VA experiment.

${ }^{\mathrm{g}}$ In 2004, the mean number (rather than percentage) of infected blossom clusters per tree was reported in Michigan.

${ }^{\mathrm{h}}$ The surfactant Break-Thru was included in the BlightBan A506 applications at 1 to 5\% bloom only at rates of 0.5\% in Michigan and New York in 2005 and $0.1 \%$ in New York in 2006. 
6). Increasing the density of cells in the formulated product from $1 \times 10^{10}$ to $1 \times$ $10^{11} \mathrm{CFU} / \mathrm{g}$ did not appear to affect incidence of colonization; similarly, the addition of Break-Thru in the first application at 1 to $5 \%$ bloom did not affect incidence (Table 6). Stigma colonization by Pantoea agglomerans C9-1 (range of 55.0 to $99.0 \%$ ) was consistently better than that of Pseudomonas fluorescens A506, and also usually exceeded that of Pantoea agglomerans E325 when compared in the same experiment (Table 6). Although the incidence of Pantoea agglomerans E325 was typically lower than that of C9-1, the initial concentration of cells in the formulated product was lower in each experiment. Extent of colonization varied with location by year, with high colonization (95 to 99\%) in Michigan in 2005 and 86 to $94 \%$ in Virginia in 2006 (Table 6).

Table 3. Efficacy of biological control agent Pantoea agglomerans C9-1 and combinations of Pantoea agglomerans C9-1 and Pseudomonas fluorescens A506 in reducing the frequency of the blossom blight phase of fire blight at three locations in the eastern United States from 2004 through $2006^{\mathrm{a}}$

\begin{tabular}{|c|c|c|c|c|c|c|c|c|}
\hline \multirow[b]{2}{*}{ Location (year) } & \multicolumn{5}{|c|}{ Application timing ${ }^{b}$} & \multirow{2}{*}{$\begin{array}{c}\text { \% Blossom } \\
\text { blight }^{c}\end{array}$} & \multicolumn{2}{|c|}{$\%$ Reduction in blossom blight ${ }^{\mathrm{d}}$} \\
\hline & $1-5 \%$ & $20-30 \%$ & $70-80 \%$ & $100 \%$ & $\mathbf{P F}$ & & C9-1 & Agri-Mycin $^{e}$ \\
\hline \multicolumn{9}{|l|}{ Experiments testing C9-1 } \\
\hline E. Lansing, MI (2004) & $\ldots$ & $\mathrm{X}$ & $\mathrm{X}$ & $\ldots$ & $\ldots$ & $56.4^{\mathrm{f}}$ & $34.4 *$ & $96.3 *$ \\
\hline Geneva, NY (2004) & $\ldots$ & $\mathrm{X}$ & $\ldots$ & $\mathrm{X}$ & $\ldots$ & 57.2 & $33.9 *$ & $44.1 *$ \\
\hline E. Lansing, MI (2005) & $\ldots$ & $\mathrm{X}$ & $\mathrm{X}$ & $\ldots$ & $\ldots$ & 4.2 & 58.4 & $70.3^{*}$ \\
\hline Geneva, NY (2005) & $\ldots$ & $\mathrm{X}$ & $\mathrm{X}$ & $\ldots$ & $\ldots$ & 32.7 & 0.3 & $80.2^{*}$ \\
\hline Winchester, VA (2005) & $\mathrm{X}$ & $\ldots$ & $\ldots$ & $\mathrm{X}$ & $\mathrm{X}$ & 30.1 & 5.6 & $46.7 *$ \\
\hline E. Lansing, MI (2006) & $\ldots$ & $\mathrm{X}$ & $\mathrm{X}$ & $\mathrm{X}$ & $\ldots$ & 13.9 & $82.6^{*}$ & $96.9 *$ \\
\hline Geneva, NY (2006) & $\ldots$ & $\mathrm{X}$ & $\mathrm{X}$ & $\ldots$ & $\ldots$ & 59.3 & 22.9 & $44.7 *$ \\
\hline Geneva, NY (2006) & $X^{g}$ & $\mathrm{X}$ & $\mathrm{X}$ & $\ldots$ & $\ldots$ & 44.7 & $41.9^{*}$ & $70.3 *$ \\
\hline \multirow[t]{2}{*}{ Winchester, VA (2006) } & $\mathrm{X}$ & $\ldots$ & $\ldots$ & $\mathrm{X}$ & $\mathrm{X}$ & 26.3 & 18.1 & 19.9 \\
\hline & & & & & & MEAN: & 33.1 & 63.3 \\
\hline \multicolumn{9}{|c|}{ Experiments testing C9-1 + A506 } \\
\hline E. Lansing, MI (2004) & $\ldots$ & $\mathrm{X}$ & $\mathrm{X}$ & $\ldots$ & $\ldots$ & 59.6 & $30.7 *$ & $96.3^{*}$ \\
\hline Geneva, NY (2004) & $\ldots$ & $\mathrm{X}$ & $\ldots$ & $\mathrm{X}$ & $\ldots$ & 72.3 & 16.5 & $44.1 *$ \\
\hline E. Lansing, MI (2005) & $\ldots$ & $\mathrm{X}$ & $X$ & $\ldots$ & $\ldots$ & 2.9 & $71.3^{*}$ & $70.3^{*}$ \\
\hline Geneva, NY (2005) & $\ldots$ & $\mathrm{X}$ & $\mathrm{X}$ & $\ldots$ & $\ldots$ & 38.2 & -16.5 & $80.2 *$ \\
\hline Winchester, VA (2005) & $\mathrm{X}$ & . & $\ldots$ & $\mathrm{X}$ & $\mathrm{X}$ & 33.3 & -4.4 & $46.7 *$ \\
\hline E. Lansing, MI (2006) & $\ldots$ & $\mathrm{X}$ & $\mathrm{X}$ & $\mathrm{X}$ & $\ldots$ & 9.3 & $88.4 *$ & $96.9 *$ \\
\hline Geneva, NY (2006) & $\ldots$ & $\mathrm{X}$ & $\mathrm{X}$ & $\ldots$ & $\ldots$ & 58.7 & 23.7 & $44.7 *$ \\
\hline Geneva, NY (2006) & $X^{g}$ & $X$ & $X$ & $\ldots$ & $\ldots$ & 61.9 & 19.5 & $44.7 *$ \\
\hline \multirow[t]{2}{*}{ Winchester, VA (2006) } & $\mathrm{X}$ & $\ldots$ & $\ldots$ & $\mathrm{X}$ & $\mathrm{X}$ & 29.1 & 9.3 & 19.9 \\
\hline & & & & & & MEAN: & 26.5 & 60.4 \\
\hline
\end{tabular}

${ }^{\text {a }}$ Trees were inoculated with Erwinia amylovora strains Ea110 at $10^{6} \mathrm{CFU} / \mathrm{ml}$ (MI), Ea273 at $10^{7} \mathrm{CFU} / \mathrm{ml}(\mathrm{NY})$, or AFRS581 at $10^{6} \mathrm{CFU} / \mathrm{ml}$ (VA). Inoculations were typically made at $100 \%$ bloom. BlightBan A506 was applied at a rate of $0.2 \mathrm{~g} /$ liter in MI, $0.7 \mathrm{~g} /$ liter in NY, $0.7 \mathrm{~g} /$ liter in VA (2002), and 0.5 $\mathrm{g} /$ liter in VA (2005 and 2006). Cell suspension density was $1 \times 10^{10} \mathrm{CFU} / \mathrm{g}$ unless otherwise noted.

${ }^{\mathrm{b}}$ Materials were applied to trees when the indicated percentage of flowers were open or at petal fall (PF).

${ }^{\mathrm{c}}$ Mean percentage of blossom clusters infected.

${ }^{\mathrm{d}}$ Comparison of frequency of blossom blight in biological control treatments versus frequencies in nontreated control treatments. Positive numbers denote the frequency of disease control. Asterisks indicate the respective treatment result was significantly different $(P \leq 0.05)$ from the nontreated control.

e The Agri-Mycin standard was used at a rate of $100 \mu \mathrm{g} / \mathrm{ml}$ and applied 1 day prior to and 1 day following inoculation in Michigan and New York and at 50 $\mu \mathrm{g} / \mathrm{ml}$ the day before inoculation in 2005 and 2006 in Virginia.

${ }_{\mathrm{f}}$ In 2004, the mean number (rather than percentage) of infected blossom clusters per tree was reported in Michigan.

g The surfactant Break-Thru was included in the BlightBan C9-1 and C9-1 + A506 applications at 1 to 5\% bloom only at a rate of $0.1 \%$ in New York in 2006.

Table 4. Efficacy of biological control agent Pantoea agglomerans E325 in reducing the frequency of the blossom blight phase of fire blight at three locations in the eastern United States from 2003 through $2007^{\mathrm{a}}$

\begin{tabular}{|c|c|c|c|c|c|c|c|c|}
\hline \multirow{2}{*}{$\begin{array}{l}\text { Location } \\
\text { (year and cell density) }\end{array}$} & \multicolumn{5}{|c|}{ Application timing $^{b}$} & \multirow{2}{*}{$\begin{array}{c}\text { \% Blossom } \\
\text { blight }^{c}\end{array}$} & \multicolumn{2}{|c|}{$\%$ Reduction in blossom blight } \\
\hline & $1-5 \%$ & $20-30 \%$ & $70-80 \%$ & $100 \%$ & $\mathbf{P F}$ & & E325 & Agri-Mycin $^{\mathrm{e}}$ \\
\hline $\begin{array}{l}\text { Geneva, NY (2003) } \\
\left(5 \times 10^{7} \mathrm{CFU} / \mathrm{g}\right)\end{array}$ & $\ldots$ & $\mathrm{X}$ & $\mathrm{X}$ & $\ldots$ & $\ldots$ & 31.0 & $57.5^{*}$ & $77.5^{*}$ \\
\hline $\begin{array}{l}\text { Geneva, NY (2004) } \\
\left(1 \times 10^{7} \text { CFU/g) }\right. \\
\text { Geneva, NY }(2005)\end{array}$ & $\cdots$ & $\mathrm{X}$ & $\mathrm{X}$ & $\ldots$ & $\ldots$ & 71.9 & 17.0 & $44.1 *$ \\
\hline $0.5 \mathrm{~g} /$ liter rate & $\ldots$ & $\mathrm{X}$ & $\mathrm{X}$ & $\ldots$ & $\ldots$ & 35.8 & -9.1 & $80.2 *$ \\
\hline $0.7 \mathrm{~g} /$ liter rate & $\ldots$ & $\mathrm{X}$ & $\mathrm{X}$ & $\ldots$ & $\ldots$ & 23.7 & 27.7 & $80.2 *$ \\
\hline E. Lansing, MI (2006) & $\ldots$ & $\mathrm{X}$ & $\mathrm{X}$ & $\mathrm{X}$ & $\ldots$ & 17.5 & $78.2^{*}$ & $96.9 *$ \\
\hline Geneva, NY (2006) & $\ldots$ & $\mathrm{X}$ & $\mathrm{X}$ & $\ldots$ & $\ldots$ & 61.4 & 20.2 & $44.7 *$ \\
\hline Winchester, VA (2006) & $\mathrm{X}$ & $\ldots$ & $\ldots$ & $\mathrm{X}$ & $\mathrm{X}$ & 30.5 & 5.0 & 19.9 \\
\hline E. Lansing, MI (2007) & $\ldots$ & $\mathrm{X}$ & $X$ & $\ldots$ & $\ldots$ & 45.8 & $31.1 *$ & $94.7 *$ \\
\hline & & & & & & MEAN: & 28.5 & 67.3 \\
\hline
\end{tabular}

${ }^{a}$ Trees were inoculated with Erwinia amylovora strains Ea110 at $10^{6} \mathrm{CFU} / \mathrm{ml}(\mathrm{MI})$, Ea273 at $10^{7} \mathrm{CFU} / \mathrm{ml}(\mathrm{NY})$, or AFRS581 at $10^{6} \mathrm{CFU} / \mathrm{ml}$ (VA). Inoculations were typically made at $100 \%$ bloom. BlightBan A506 was applied at a rate of $0.2 \mathrm{~g} /$ liter in MI, $0.7 \mathrm{~g} / \mathrm{liter}$ in NY, $0.7 \mathrm{~g} /$ liter in VA (2002), and 0.5 $\mathrm{g} /$ liter in VA (2005 and 2006). Cell suspension density was $1 \times 10^{10} \mathrm{CFU} / \mathrm{g}$ unless otherwise noted.

$\mathrm{b}$ Materials were applied to trees when the indicated percentage of flowers were open or at petal fall (PF).

${ }^{\mathrm{c}}$ Mean percentage of blossom clusters infected.

${ }^{\mathrm{d}}$ Comparison of frequency of blossom blight in biological control treatments versus frequencies in nontreated control treatments. Positive numbers denote the frequency of disease control. Asterisks indicate the respective treatment result was significantly different $(P \leq 0.05)$ from the nontreated control.

e The Agri-Mycin standard was used at a rate of $100 \mu \mathrm{g} / \mathrm{ml}$ and applied 1 day prior to and 1 day following inoculation in Michigan and New York and at 50 $\mu \mathrm{g} / \mathrm{ml}$ the day before inoculation in 2006 in Virginia. 
Integration of biological control agents with streptomycin for blossom blight control. We evaluated the efficacy of various biological control agents integrated into programs with streptomycin for blossom blight control in nine experiments. The premise of these experiments was to compare programs utilizing biological control and a reduced number of streptomycin applications (usually one) to a standard program incorporating additional streptomycin applications (usually two). In seven of the nine experiments, integration of a biological control agent with Agri-Mycin resulted in blossom blight incidences that were not significantly different from treatments incorporating Agri-Mycin alone with additional applications (Table 7). Increases in efficacy through integration were observed at all three experimental field locations and at least twice with all of the biological control agents used in this study (Table 7). In each experiment, the number of AgriMycin applications was reduced by one, except in Virginia in 2006, where the number of Agri-Mycin applications was reduced by two.

\section{DISCUSSION}

Our results indicate that biological control efforts with bacterial antagonists were largely ineffective in reducing the incidence of blossom blight in field trials with inoculated trees in Michigan, New York, and Virginia. The requirements for bacterial antagonists to be successful in biological control of blossom blight include the colonization of a large proportion of flower stigmata with growth to a large population size (ca. $10^{5}$ to $10^{6} \mathrm{CFU}$ per blossom) $(5,6,11)$. In commercial orchards, the antagonists are typically applied at least twice prior to full bloom, to allow time for bacterial growth, dissemination, and colonization of open flowers, including flowers that were not open at the time of application. The mechanism of biological control by the commercialized Pantoea agglomerans antagonists and other $P$. agglomerans strains studied includes antibiosis and competitive inhibition $(3,4,29)$. In contrast, the mode of action of Pseudomonas fluorescens A506 in blossom blight control is competitive exclusion (35). Thus, it is critical that the bacterial antagonists are present, growing, and producing antibiotics in the case of Pantoea agglomerans, prior to the arrival of the pathogen. Implicit in this assumption is that the antagonists grow or utilize available resources faster than E. amylovora when both arrive at a stigma simultaneously or when the arrival of the antagonist precedes that of the pathogen by only a short time period. Another assumption is that the bacterial antagonists colonize similar microsites on stigmas as E. amylovora, which may not be true based on confocal microscopy observations (28).

Of the three bacterial antagonists examined in this study, Pseudomonas fluorescens A506 exhibited the least potential biological control activity and colonized the lowest percentage of flowers (mean colonization of $61 \%$ in 13 experiments, Table 6). Pseudomonas fluorescens A506 has shown the most promise in fire blight control in pear orchards in the western United States, and the organism is also important in suppressing frost injury and fruit russeting (11). Colonization studies in the Pacific Northwest also indicate that Pseudomonas fluorescens A506 colonizes a relatively low percentage of flowers (5); however, an average of 40 to $60 \%$ reduction in blossom blight incidence has been observed in experiments conducted in Oregon and California $(5,6,11)$, which is much greater than we observed.

While the mean reduction in the percentage of blossom blight observed in experiments using Pantoea agglomerans C9-1 or E325 was greater than that in experiments using Pseudomonas fluorescens A506, these levels only exceeded 50\% in 4

Table 5. Efficacy of different formulations of the biological control agent Serenade (Bacillus subtilis QST713) in reducing the frequency of the blossom blight phase of fire blight at three locations in the eastern United States from 2001 to $2006^{\mathrm{a}}$

\begin{tabular}{|c|c|c|c|c|c|c|c|c|}
\hline \multirow{2}{*}{$\begin{array}{l}\text { Experiment location (year) } \\
\text { formulation and rate }\end{array}$} & \multicolumn{5}{|c|}{ Application timing ${ }^{b}$} & \multirow{2}{*}{$\begin{array}{c}\text { \% Blossom } \\
\text { blightc }^{c}\end{array}$} & \multicolumn{2}{|c|}{$\%$ Reduction in blossom blight ${ }^{\mathrm{d}}$} \\
\hline & $1-5 \%$ & $20-30 \%$ & $70-80 \%$ & $100 \%$ & PF & & Serenade & Agri-Mycin \\
\hline \multicolumn{9}{|l|}{ Geneva, NY (2001) } \\
\hline WP $(2.3 \mathrm{~g} /$ liter $)$ & $\ldots$ & $\ldots$ & $\mathrm{X}$ & $\mathrm{X}$ & $\ldots$ & 43.8 & $27.6^{*}$ & $55.4^{*}$ \\
\hline \multicolumn{9}{|l|}{ Geneva, NY (2002) } \\
\hline WP10 (3.6 g/liter) & $\ldots$ & $\ldots$ & $\mathrm{X}$ & $\mathrm{X}$ & $\ldots$ & 32.9 & $49.8 *$ & $86.4 *$ \\
\hline \multicolumn{9}{|l|}{ Geneva, NY (2003) } \\
\hline QRD141 (2.4 g/liter) & $\ldots$ & $\ldots$ & $\mathrm{X}$ & $\mathrm{X}$ & $\ldots$ & 31.7 & $56.6^{*}$ & $77.5^{*}$ \\
\hline \multicolumn{9}{|l|}{ Winchester, VA (2003) } \\
\hline QRD141 (2.4 g/liter) & $\ldots$ & $\ldots$ & $\mathrm{X}$ & $\mathrm{X}$ & $\mathrm{X}$ & 14.4 & $41.7^{*}$ & $62.3^{*}$ \\
\hline \multicolumn{9}{|l|}{ E. Lansing, MI (2004) } \\
\hline ASO $(5 \mathrm{ml} /$ liter $)$ & $\ldots$ & $\ldots$ & $\mathrm{X}$ & $\ldots$ & $\mathrm{X}$ & $37.0^{\mathrm{f}}$ & $57.0 *$ & $96.3 *$ \\
\hline \multicolumn{9}{|l|}{ Geneva, NY (2004) } \\
\hline 10WP (2.8 g/liter) & $\ldots$ & $\ldots$ & $\ldots$ & $\mathrm{X}$ & $\mathrm{X}^{\mathrm{a}}$ & 68.1 & $21.4 *$ & $44.1^{*}$ \\
\hline \multicolumn{9}{|l|}{ E. Lansing, MI (2005) } \\
\hline $\operatorname{MAX}(0.8 \mathrm{~g} / \text { liter })^{\mathrm{g}}$ & $\ldots$ & $\mathrm{X}$ & $\mathrm{X}$ & $\ldots$ & $\ldots$ & 3.3 & $67.3^{*}$ & $70.3^{*}$ \\
\hline \multicolumn{9}{|l|}{ E. Lansing, MI (2005) } \\
\hline $\operatorname{MAX}(0.8 \mathrm{~g} / \text { liter })^{\mathrm{g}}$ & $\ldots$ & $\ldots$ & $\mathrm{X}$ & $\mathrm{X}$ & $\ldots$ & 2.8 & $82.7 *$ & $85.8^{*}$ \\
\hline \multicolumn{9}{|l|}{ Geneva, NY (2005) } \\
\hline MAX $(1.0 \mathrm{~g} /$ liter $)$ & $\ldots$ & $\mathrm{X}$ & $\mathrm{X}$ & $\ldots$ & $\ldots$ & 44.2 & -34.8 & $80.2 *$ \\
\hline \multicolumn{9}{|l|}{ Winchester, VA (2005) } \\
\hline $\operatorname{MAX}(0.9 \mathrm{~g} / \text { liter })^{\mathrm{g}}$ & $\mathrm{X}$ & $\ldots$ & $\ldots$ & $\mathrm{X}$ & $\mathrm{X}$ & 27.5 & 13.8 & $46.7 *$ \\
\hline \multicolumn{9}{|l|}{ Winchester, VA (2006) } \\
\hline \multirow[t]{2}{*}{$\operatorname{MAX}\left(0.9 \mathrm{~g} / \mathrm{liter}^{\mathrm{g}}\right.$} & $\mathrm{X}$ & $\ldots$ & $\ldots$ & $\mathrm{X}$ & $\mathrm{X}$ & 27.5 & 14.4 & 19.9 \\
\hline & & & & & & MEAN: & 36.1 & 65.9 \\
\hline
\end{tabular}

a Trees were inoculated with Erwinia amylovora strains Ea110 at $10^{6} \mathrm{CFU} / \mathrm{ml}(\mathrm{MI})$, Ea273 at $10^{7} \mathrm{CFU} / \mathrm{ml}(\mathrm{NY})$, or AFRS581 at $10^{6} \mathrm{CFU} / \mathrm{ml}$ (VA). Inoculations were typically made at $100 \%$ bloom.

${ }^{\mathrm{b}}$ Materials were applied to trees when the listed percentage of blossoms were open or at petal fall (PF).

${ }^{\mathrm{c}}$ Mean values of proportion of infected blossom clusters per tree.

${ }^{\mathrm{d}}$ Comparison of frequency of blossom blight in biological control treatments versus frequencies in nontreated control treatments. Positive numbers denote the frequency of disease control. Asterisks indicate the respective treatment result was significantly different $(P \leq 0.05)$ from the nontreated control.

e The Agri-Mycin standard was used at a rate of $100 \mu \mathrm{g} / \mathrm{ml}$ and applied 1 day prior to and 1 day following inoculation in Michigan and New York. In Virginia, Agri-Mycin was applied at $100 \mu \mathrm{g} / \mathrm{ml}$ three times with inoculation the day of the first and third applications in 2003 , and at $50 \mu \mathrm{g} / \mathrm{ml}$ the day before inoculation in 2005 and 2006.

${ }^{\mathrm{f}}$ In 2004, the mean value of total infected blossom clusters per tree was reported in Michigan.

$\mathrm{g}$ Biotune $(0.125 \% \mathrm{vol} / \mathrm{vol})$ was added as a surfactant. 
of 17 experiments. In addition, the slightly higher percentage of flowers colonized by Pantoea agglomerans C9-1 in our experiments did not correlate with increased efficacy against blossom blight. As with Pseudomonas fluorescens A506, Pantoea agglomerans C9-1 showed increased efficacy in studies conducted in Oregon with average of 40 to $70 \%$ reduction in blossom blight incidence (29).

Commercially formulated mixtures of Pseudomonas fluorescens A506 and Pantoea agglomerans C9-1 have also been examined in an attempt to improve efficacy. However, even though both strains are capable of co-colonization of flower stigmata, the efficacy of mixtures has generally not exceeded that of the single strains (5; results of this study). Recently, Pseudomonas fluorescens A506 was demonstrated to secrete a protease that inactivated the antibiotic produced by Pantoea agglomerans C9-1 (1). Subsequent field trials utilizing a protease-deficient deletion mutant of Pseudomonas fluorescens A506 (A506 $\triangle a p r X$ ) in combination with Pantoea agglomerans $\mathrm{C} 9-1$ resulted in a numerical increase in percent disease reduction compared to an A506 + C9-1 combination in five experimental trials, although the difference was not significant in any trial (30). The results of a separate study indicated that Pseudomonas fluorescens A506 produces an antibiotic in the presence of elevated iron conditions that is inhibitory to E. amylovora (31). However, iron availability on flower stigmata is limited, making it unlikely that this antibiotic is produced on apple flowers that are not amended with iron (31). These new observations indicate that there is still much to learn concerning the biology and ecology of Pseudomonas fluorescens A506 and Pantoea agglomerans C9-1. Likewise, it is also critical that a knowledge base is gained of E. amylovora virulence factors that enhance colonization of stigmata $(19,37)$, as well as the physical partitioning of the pathogen in this habitat. An increased understanding of the ecology of both pathogen and bacterial antagonists in the stigma habitat holds promise that new insights could lead to altered strategies that could increase biological control efficacy.

It is evident from our results that commercial formulations of bacterial antagonists are not as efficacious in controlling blossom blight in the eastern United States as they are in the western United States. Temperature during the application of antagonistic bacteria may have played a part in how well the bacteria established themselves on the stigmatic surfaces of the flowers. The temperature for optimal growth of E. amylovora ranges from 24 to $29^{\circ} \mathrm{C}$ (23). The temperature for optimal growth of Pseudomonas fluorescens A506 is $25^{\circ} \mathrm{C}$, of Pantoea agglomerans $\mathrm{C} 9-1$ is $32^{\circ} \mathrm{C}$, and of Pantoea agglomerans E325 is $28^{\circ} \mathrm{C}$ (23). For example, temperatures reached 24 and $25^{\circ} \mathrm{C}$ on each of two dates of application with C9-1 in Michigan in
2005, and $99 \%$ of blossoms were colonized (Table 1). The following year, when the maximum daily temperatures of the two application dates were 19 and $24^{\circ} \mathrm{C}$, colonization of blossoms with $\mathrm{C} 9-1$ was 83\% (Table 1). In Virginia, maximum daily temperatures on the dates of application of the antagonists in 2005 were 27, 17, and $15^{\circ} \mathrm{C}$, and blossom colonization ranged from 50 to $60 \%$ (Table 4). In the following year, maximum daily temperatures on treatment dates were 23,13 , and $25^{\circ} \mathrm{C}$, and colonization ranged from 86 to $94 \%$ (Table 1). Although temperatures were reasonably high $\left(27^{\circ} \mathrm{C}\right)$ for 2 days following the early treatment in 2005, population levels were not as high as in 2006 when the temperature reached $25^{\circ} \mathrm{C}$ on the final day of treatment. This may indicate the importance of consistently high temperatures in maintaining high population levels of the antagonists.

The previous results support the findings of Nuclo et al. (18) and Johnson et al. (8), which described low colonization and spread of antagonists under conditions of low temperatures. For example, in 2004, C9-1 provided $34 \%$ reduction in blossom blight and minimum daily temperatures never fell below $12^{\circ} \mathrm{C}$; yet in the next year, C9-1 provided no reduction of blight and minimum daily temperatures reached $-1^{\circ} \mathrm{C}$. Correlations between temperature and efficacy are difficult to make without conducting controlled temperature experiments on live plant tissue. Johnson et al.

Table 6. Incidence of three bacterial antagonists (Pseudomonas fluorescens A506, Pantoea agglomerans C9-1, Pantoea agglomerans E325) following application to apple trees measured by imprinting stigmata on selective media in Michigan, New York, and Virginia

\begin{tabular}{|c|c|c|c|c|c|c|c|}
\hline \multirow[b]{2}{*}{ Location (year) } & \multirow{2}{*}{$\begin{array}{c}\text { Formulation treatment } \\
(\mathrm{CFU} / \mathrm{g})^{\mathrm{a}}\end{array}$} & \multicolumn{5}{|c|}{ Application timing } & \multirow{2}{*}{$\begin{array}{l}\text { \% Stigmata } \\
\text { colonized }^{c}\end{array}$} \\
\hline & & $1-5 \%$ & $20-30 \%$ & $70-80 \%$ & $100 \%$ & PF & \\
\hline \multirow[t]{4}{*}{ E. Lansing, MI (2005) } & A506 $\left(10^{10}\right)$ & $\ldots$ & $\mathrm{X}$ & $\mathrm{X}$ & $\ldots$ & $\ldots$ & $96.2(2.3)$ \\
\hline & $\mathrm{A} 506\left(10^{11}\right)$ & $\ldots$ & $\mathrm{X}$ & $\mathrm{X}$ & $\ldots$ & $\ldots$ & $96.2(2.8)$ \\
\hline & A506 $\left(10^{10}\right) ; \mathrm{BT}$ & $X$ & $X$ & $\mathrm{X}$ & $\ldots$ & $\ldots$ & $95.2(2.6)$ \\
\hline & C9-1 $\left(10^{11}\right)$ & $\ldots$ & $\mathrm{X}$ & $X$ & $\ldots$ & $\ldots$ & $99.0(0.9)$ \\
\hline \multirow[t]{10}{*}{ Geneva, NY (2005) } & $\mathrm{A} 506\left(10^{10}\right)$ & $\ldots$ & $\mathrm{X}$ & $\ldots$ & $\ldots$ & $\ldots$ & $45.6(1.4)$ \\
\hline & $\operatorname{A506}\left(10^{11}\right)$ & $\ldots$ & $\mathrm{X}$ & $\ldots$ & $\ldots$ & $\ldots$ & $26.4(0.5)$ \\
\hline & A506 $\left(10^{10}\right) ; \mathrm{BT}$ & $\ldots$ & $\mathrm{X}$ & $\ldots$ & $\ldots$ & $\ldots$ & $73.8(1.5)$ \\
\hline & C9-1 $\left(10^{11}\right)$ & $\ldots$ & $\mathrm{X}$ & $\ldots$ & $\ldots$ & $\ldots$ & $76.3(0.8)$ \\
\hline & $\mathrm{E} 325\left(10^{10}\right)$ & $\ldots$ & $\mathrm{X}$ & $\ldots$ & $\ldots$ & $\ldots$ & $43.3(2.7)$ \\
\hline & $\operatorname{A5} 06\left(10^{10}\right)$ & $\ldots$ & $\ldots$ & $\mathrm{X}$ & $\ldots$ & $\ldots$ & $48.6(1.1)$ \\
\hline & $\operatorname{A5} 06\left(10^{11}\right)$ & $\ldots$ & $\ldots$ & $\mathrm{X}$ & $\ldots$ & $\ldots$ & $44.1(1.7)$ \\
\hline & A506 $\left(10^{10}\right) ; \mathrm{BT}$ & $\ldots$ & $\ldots$ & $\mathrm{X}$ & $\ldots$ & $\ldots$ & $50.8(0.9)$ \\
\hline & C9-1 $\left(10^{11}\right)$ & $\ldots$ & $\ldots$ & $\mathrm{X}$ & $\ldots$ & $\ldots$ & $85.0(0.4)$ \\
\hline & E325 $\left(10^{10}\right)$ & $\ldots$ & $\ldots$ & $\mathrm{X}$ & $\ldots$ & $\ldots$ & $58.0(0.6)$ \\
\hline \multirow[t]{3}{*}{ Winchester, VA (2005) } & A506 $\left(10^{10}\right)$ & X & $\begin{array}{l}\cdots \\
\cdots\end{array}$ & $\ldots$ & $\dddot{x}$ & X & $59.5(5.6)$ \\
\hline & $\operatorname{A} 506\left(10^{11}\right)$ & $\mathrm{X}$ & $\ldots$ & $\ldots$ & $\mathrm{X}$ & $\mathrm{X}$ & $49.5(10.3)$ \\
\hline & C9-1 $\left(10^{11}\right)$ & $\mathrm{X}$ & $\ldots$ & $\ldots$ & $\mathrm{X}$ & $\mathrm{X}$ & $87.0(4.9)$ \\
\hline \multirow[t]{2}{*}{ E. Lansing, MI (2006) } & C9-1 $\left(10^{11}\right)$ & $\ldots$ & $\mathrm{X}$ & $\mathrm{X}$ & $\ldots$ & $\ldots$ & $83.3(10.4)$ \\
\hline & E325 $\left(10^{10}\right)$ & $\ldots$ & $\mathrm{X}$ & $\mathrm{X}$ & $\ldots$ & $\ldots$ & $60.7(3.6)$ \\
\hline \multirow[t]{3}{*}{ Geneva, NY (2006) } & A506 $\left(10^{10}\right)$ & $\ldots$ & $\ldots$ & $\mathrm{X}$ & $\ldots$ & $\ldots$ & $23.0(1.8)$ \\
\hline & C9-1 $\left(10^{11}\right)$ & $\ldots$ & $\ldots$ & $\mathrm{X}$ & $\ldots$ & $\ldots$ & $55.0(1.4)$ \\
\hline & E325 $\left(10^{10}\right)$ & $\ldots$ & $\begin{array}{l}\cdots \\
\ldots\end{array}$ & $\mathrm{X}$ & $\begin{array}{l}\cdots \\
\cdots\end{array}$ & $\begin{array}{l}\cdots \\
\cdots\end{array}$ & $35.0(0.7)$ \\
\hline \multirow[t]{3}{*}{ Winchester, VA (2006) } & $\operatorname{A506}\left(10^{10}\right)$ & $\mathrm{X}$ & $\ldots$ & $\ldots$ & $\mathrm{X}$ & $\mathrm{X}$ & $86.1(5.3)$ \\
\hline & C9-1 $\left(10^{11}\right)$ & $X$ & $\ldots$ & $\ldots$ & $X$ & $\mathrm{X}$ & $94.4(3.9)$ \\
\hline & $\mathrm{E} 325\left(10^{10}\right)$ & $\mathrm{X}$ & $\ldots$ & $\ldots$ & $\mathrm{X}$ & $\mathrm{X}$ & $91.7(4.8)$ \\
\hline
\end{tabular}

${ }^{a}$ BlightBan A506 and BlightBan C9-1 were applied at a rate of $0.2 \mathrm{~g} /$ liter in MI, $0.7 \mathrm{~g} /$ liter in NY, and 0.5 g/liter in VA. Bloomtime E325 was applied at a rate of $0.6 \mathrm{~g} /$ liter in MI and $0.5 \mathrm{~g} /$ liter in NY and VA. BT indicates the surfactant Break-Thru was incorporated in the 1 to $5 \%$ bloom application in MI and in the designated application in NY.

${ }^{\mathrm{b}}$ Materials were applied to trees when the indicated percentage of flowers were open or at petal fall (PF).

${ }^{\mathrm{c}}$ Mean values shown with standard error of the mean in parentheses. 
(7) created a decision matrix based on data from both growth chamber and screenhouse experiments and the temperaturedependent forecasting model, COUGARBLIGHT. They determined that, by using a 4-day forecast of bacterial growth indices they established for BlightBan A506 and C9-1, poor growth conditions for the antagonists can be avoided. The decision matrix designed in their study was based on temperature and bloom stage at which the application was made. This highlights the importance of providing sufficient lead time for antagonists to colonize flowers prior to inoculation with the pathogen in designed studies. The efficacy of treatments in the 2002 Virginia trial was likely lower than in later years because the antagonists were given just over $24 \mathrm{~h}$ to colonize the stigmatic surfaces.

Our results indicate that the biological control Serenade (active ingredient: lipopeptides produced by B. subtilis QST713) was slightly more efficacious in blossom blight control than the bacterial antagonists and more consistent from year to year and between locations. Serenade has also shown promise in the control of mummyberry disease of blueberry, caused by Monilinia vaccinii-corymbosi, another pathogen that infects flowers via the stigma (26). Since the activity and application timing of this product is more similar to antibiotics, it is likely that coverage of flowers is increased compared to colonization by bacterial antagonists. However, the efficacy of Serenade still did not approach that of streptomycin when it was applied similarly, indicating the superior activity of streptomycin against E. amylovora when both of these materials are used at recommended rates.

The integration of biological control materials with streptomycin in disease control regimes resulted in significant reductions in blossom blight in all of 17 comparisons with nontreated controls (Table 7). While it is likely that this observation again indicates the superior efficacy of streptomycin, it is noteworthy that the number of applications of streptomycin was reduced from two or three to one in 15 of the 17 experimental treatments. Streptomycin resistance is widespread in the western United States and in some regions of Michigan (15); however, except for an isolated occurrence in New York (25), resistance has not been reported from New York, Virginia, or northwestern Michigan (H. S. Aldwinckle, G. W. Sundin, and K. S. Yoder, unpublished). Prevailing hypotheses regarding the selection of antibiotic resistance in bacterial populations implicate the number of applications per season or timing of exposure with the possibility of resistance development. Consistent with these hypotheses is the observation that streptomycin usage in the western United States for fire blight control was much greater (minimum of 10 to 14 applications per season) than that in the eastern United States (up to five applications per season), and also involved postbloom applications $(9,17)$. In Michigan, a location where streptomycin resistance has emerged in E. amylovora populations, growers were applying either postbloom or prebloom streptomycin sprays routinely (17). Thus, the integration of biological control materials with streptomycin in blossom blight management programs has the potential to reduce streptomycin use, which may enhance resistance management and reduce the possibility for streptomycin resistance development in New York and Virginia.

In summary, the bacterial antagonists Pseudomonas fluorescens A506 and Pantoea agglomerans $\mathrm{C} 9-1$ and $\mathrm{E} 325$, and the biological control agent Serenade were insufficiently effective in controlling blossom blight when applied as the sole control agent in trials conducted in Michigan, New York, and Virginia. This low efficacy was also associated with high year-to-year and location-to-location variability. Alternatives to streptomycin are desperately needed, as the impact of fire blight continues to increase due to the planting of new apple varieties that are popular with consumers but highly susceptible to the disease. However, materials with high variability in control performance are not good options for growers. We will continue to search for effective streptomycin alternatives for fire blight control and also examine integrated approaches that decrease the number of streptomycin applications needed yet retain commercially acceptable levels of control.

Table 7. Efficacy of biological control agents and Agri-Mycin in reducing the incidence of the blossom blight phase of fire blight at three locations in the eastern United States from 2002 through 2007

\begin{tabular}{|c|c|c|}
\hline Experiment location (year) & $\begin{array}{l}\text { Experimental treatments } \\
\text { (no. of applications) }\end{array}$ & $\%$ Blossom blight $^{\mathrm{c}}$ \\
\hline Geneva, NY (2002) & $\begin{array}{l}\text { Agri-Mycin (2) } \\
\text { Serenade WP10 (1), Agri-Mycin (1) } \\
\text { Control }\end{array}$ & $\begin{array}{l}8.9^{*} \\
27.2^{*} \\
65.5\end{array}$ \\
\hline Winchester, VA (2002) & $\begin{array}{l}\text { Agri-Mycin (2) } \\
\text { Serenade QRD137 (1), Agri-Mycin (1) } \\
\text { Control }\end{array}$ & $\begin{array}{l}30.6^{*} \\
46.9^{*} \ddagger \\
76.5\end{array}$ \\
\hline Geneva, NY (2003) & $\begin{array}{l}\text { Agri-Mycin (2) } \\
\text { Bloomtime Biol. E325 (1), Agri-Mycin (1) } \\
\text { Control }\end{array}$ & $\begin{array}{l}16.4^{*} \\
25.8^{*} \\
73.0\end{array}$ \\
\hline Winchester, VA (2003) & $\begin{array}{l}\text { Agri-Mycin (3) } \\
\text { Agri-Mycin (1), Serenade QRD141 (2) } \\
\text { Control }\end{array}$ & $\begin{array}{l}7.5^{*} \\
15.5^{*} \ddagger \\
24.7\end{array}$ \\
\hline Geneva, NY (2004) & $\begin{array}{l}\text { Agri-Mycin (3) } \\
\text { BlightBan A506 (1), Agri-Mycin (2) } \\
\text { Control }\end{array}$ & $\begin{array}{l}48.4^{*} \\
49.4^{*}+ \\
86.6\end{array}$ \\
\hline Winchester, VA (2005) & $\begin{array}{l}\text { Agri-Mycin (3) } \\
\text { BlightBan A506 (2), Agri-Mycin (1) } \\
\text { BlightBan C9-1 (2), Agri-Mycin (1) } \\
\text { BlightBan C9-1+A506 (2), Agri-Mycin (1) } \\
\text { Serenade MAX (2), Agri-Mycin (1) } \\
\text { Control }\end{array}$ & $\begin{array}{l}17.0^{*} \\
25.0^{*} \\
21.6^{*}+ \\
31.3^{*} \\
15.2^{*}+ \\
31.9\end{array}$ \\
\hline East Lansing, MI (2006) & $\begin{array}{l}\text { Agri-Mycin (2) } \\
\text { BlightBan C9-1 (2), Agri-Mycin (1) } \\
\text { BlightBan C9-1+A506 (2), Agri-Mycin (1) } \\
\text { Bloomtime Biol. E325 (1), Agri-Mycin (1) } \\
\text { Control }\end{array}$ & $\begin{aligned} & 2.5^{*} \\
& 3.4^{* \dagger} \\
& 4.9^{*+}+ \\
& 3.2^{*}+ \\
& 80.1\end{aligned}$ \\
\hline Winchester, VA (2006) & $\begin{array}{l}\text { Agri-Mycin (3) } \\
\text { BlightBan A506 (1), Agri-Mycin (2) } \\
\text { BlightBan C9-1 (2), Agri-Mycin (1) } \\
\text { BlightBan C9-1+A506 (2), Agri-Mycin (1) } \\
\text { Bloomtime Biol. E325 (1), Agri-Mycin (1) } \\
\text { Control }\end{array}$ & $\begin{array}{l}25.7 * \\
31.5 * \ddagger \\
23.5^{*}+ \\
29.1 * \ddagger \\
31.8^{*}+ \\
32.1\end{array}$ \\
\hline E. Lansing, MI (2007) & $\begin{array}{l}\text { Agri-Mycin (2) } \\
\text { Bloomtime Biol. E325 (1), Agri-Mycin (1) } \\
\text { Control }\end{array}$ & $\begin{array}{l}3.5^{*} \\
8.8^{*}+ \\
66.5\end{array}$ \\
\hline
\end{tabular}

a All trees in experiments were inoculated with Erwinia amylovora strains Ea110 at $10^{6} \mathrm{CFU} / \mathrm{ml}$ (MI), Ea273 at $10^{7} \mathrm{CFU} / \mathrm{ml}(\mathrm{NY})$, or AFRS581 at $10^{6} \mathrm{CFU} / \mathrm{ml}$ (VA). Inoculations were typically made at $100 \%$ bloom.

${ }^{b}$ The number of applications of each material is listed in parentheses. Application timings and material quantities are as listed in the previous tables. The Agri-Mycin standard was used at a rate of 100 $\mu \mathrm{g} / \mathrm{ml}$ and applied 1 day prior to and 1 day following inoculation in Michigan and New York. In Virginia Agri-Mycin was applied at $100 \mu \mathrm{g} / \mathrm{ml}$ the day of inoculation in 2002, at $50 \mu \mathrm{g} / \mathrm{ml}$ three times with inoculation the day of the first and third applications in 2003 , and at $50 \mu \mathrm{g} / \mathrm{ml}$ the day before inoculation in 2005 and 2006.

${ }^{c}$ Comparison of frequency of blossom blight in biological control treatments versus frequencies in nontreated control treatments. Positive numbers denote the percentage of disease control. Asterisks indicate the respective treatment result was significantly different $(P \leq 0.05)$ from the nontreated control. $\ddagger$ indicates the respective treatment result was not significantly different than the Agri-Mycin result. 


\section{ACKNOWLEDGMENTS}

This work was supported by the Michigan Apple Committee, a USDA-CSREES special grant to H.S.A. and G.W.S., IR-4 Biopesticide Research Program, Nufarm Americas, Inc., Northwest Agricultural Products, AgraQuest, Inc., and the Agricultural Experiment Stations of Michigan, New York, and Virginia. We thank Allen Cochran II, Gail Ehret, Gregg Heidenreich, Scott Kilmer, Gayle McGhee, and William Royston, Jr. for technical assistance, and thank the anonymous reviewers of this manuscript for many helpful comments.

\section{LITERATURE CITED}

1. Anderson, L. M., Stockwell, V. O., and Loper, J. E. 2004. An extracellular protease of Pseudomonas fluorescens inactivates antibiotics of Pantoea agglomerans. Phytopathology 94:1228-1234.

2. Broggini, G. A. L., Duffy, B., Holliger, E., Scharer, H.-J., Gessler, C., and Patocchi, A. 2005. Detection of the fire blight biocontrol agent Bacillus subtilis BD170 (Biopro®) in a Swiss apple orchard. Eur. J. Plant Pathol. 111:93-100.

3. Giddens, S. R., Houliston, G. J., and Mahanty, H. K. 2003. The influence of antibiotic production and pre-emptive colonization on the population dynamics of Pantoea agglomerans (Erwinia herbicola) Eh1087 and Erwinia amylovora in planta. Environ. Microbiol. 5:1016-1021.

4. Ishimaru, C. A., Klos, E. J., and Brubaker, R. R. 1988. Multiple antibiotic production by $\mathrm{Er}$ winia herbicola. Phytopathology 78:746-750.

5. Johnson, K. B., and Stockwell, V. O. 1998. Management of fire blight: A case study in microbial ecology. Annu. Rev. Phytopathol. 36:227-248.

6. Johnson, K. B., Stockwell, V. O., Burgett, D. M., Sugar, D., and Loper, J. E. 1993. Dispersal of Erwinia amylovora and Pseudomonas fluorescens by honey bees from hives to apple and pear blossoms. Phytopathology 83:479-484.

7. Johnson, K. B., Stockwell, V. O., and Sawyer, T. L. 2004. Adaptation of fire blight forecasting to optimize the use of biological controls. Plant Dis. 88:41-48.

8. Johnson, K. B., Stockwell, V. O., Sawyer, T. L., and Sugar, D. 2000. Assessment of environmental factors influencing growth and spread of Pantoea agglomerans on and among blossoms of pear and apple. Phytopathology 90:1285-1294.

9. Jones, A. L., and Schnabel, E. L. 2000. The development of streptomycin-resistant strains of Erwinia amylovora. Pages 235-251 in: Fire Blight: The Disease and its Causative Agent, Erwinia amylovora. J. L. Vanneste, ed. CABI Publishing, Oxon, UK.

10. King, E. O., Ward, M. R., and Raney, D. E.
1954. Two simple media for the demonstration of pyocyanin and fluorescin. J. Lab. Clin. Med. 44:301-307.

11. Lindow, S. E., McGourty, G., and Elkins, R. 1996. Interactions of antibiotics with Pseudomonas fluorescens strain A506 in the control of fire blight and frost injury to pear. Phytopathology 86:841-848.

12. Loper, J. E., Henkels, M. D., Roberts, R. G., Grove, G. G., Willet, M. J., and Smith, T. J. 1991. Evaluation of streptomycin and oxytetracycline and copper resistance of Erwinia amylovora isolated from pear orchards in Washington State. Plant Dis. 75:287-290.

13. McGhee, G. C., Bellomo, L., Blumer, S. E., and Sundin, G. W. 2008. Emergence and progression of streptomycin resistance in Erwinia amylovora in Michigan. Acta Hortic. 793:371374.

14. McManus, P. S., and Jones, A. L. 1994. Epidemiology and genetic analysis of streptomycin-resistant Erwinia amylovora from Michigan and evaluation of oxytetracycline for control. Phytopathology 84:627-633.

15. McManus, P. S., Stockwell, V. O., Sundin, G. W., and Jones, A. L. 2002. Antibiotic usage in plant agriculture. Annu. Rev. Phytopathol. 40:443-465.

16. Mercier, J., and Lindow, S. E. 2001. Field performance of antagonistic bacteria identified in a novel assay for biological control of fire blight of pear. Biol. Control 22:66-71.

17. Moller, W. J., Schroth, M. N., and Thomson, S. V. 1981. The scenario of fire blight and streptomycin resistance. Plant Dis. 65:563-568.

18. Nuclo, R. L., Johnson, K. B., Stockwell, V. O., and Sugar, D. 1998. Secondary colonization of pear blossoms by two bacterial antagonists of the fire blight pathogen. Plant Dis. 82:661-668.

19. Oh, C.-S., and Beer, S. V. 2005. Molecular genetics of Erwinia amylovora involved in the development of fire blight. FEMS Microbiol. Lett. 253:185-192.

20. Pujol, M., Badosa, E., Cabrefiga, J., and Montesinos, E. 2005. Development of a strainspecific quantitative method for monitoring Pseudomonas fluorescens EPS62e, a novel biocontrol agent of fire blight. FEMS Microbiol. Lett. 249:343-352.

21. Pusey, P. L. 1997. Crab apple blossoms as a model for research on biological control of fire blight. Phytopathology 87:1096-1102.

22. Pusey, P. L. 1999. Laboratory and field trials with selected microorganisms as biocontrol agents for fire blight. Acta Hortic. 489:655661.

23. Pusey, P. L., and Curry, E. A. 2004. Temperature and pomaceous flower age related to colonization by Erwinia amylovora and antagonists. Phytopathology 94:901-911.

24. Ritchie, D. R., and Klos, E. J. 1977. Isolation of Erwinia amylovora bacteriophage from the aerial parts of apple trees. Phytopathology 67:101-104.

25. Russo, N. L., Burr, T. J., Breth, D. I., and Aldwinckle, H. S. 2008. Isolation of streptomycin-resistant isolates of Erwinia amylovora in New York. Plant Dis. 92:714-718.

26. Scherm, H., Ngugi, H. K., Savelle, A. T., and Edwards, J. R. 2004. Biological control of infection of blueberry flowers caused by Monilinia vaccinii-corymbosi. Biol. Control 29:199206.

27. Schroth, M. N., Thomson, S. V., Hildebrand, D. C., and Moller, W. J. 1974. Epidemiology and control of fire blight. Annu. Rev. Phytopathol. 12:389-412.

28. Spinelli, F., Ciampolini, F., Cresti, M., Geider, K., and Costa, G. 2005. Influence of stigmatic morphology on flower colonization by Erwinia amylovora and Pantoea agglomerans. Eur. J. Plant Pathol. 113:395-405.

29. Stockwell, V. O., Johnson, K. B., Sugar, D. and Loper, J. E. 2002. Antibiosis contributes to biological control of fire blight by Pantoea agglomerans strain Eh252 in orchards. Phytopathology 92:1202-1209.

30. Stockwell, V. O., Temple, T. N., Johnson, K. B., and Loper, J. E. 2008. Integrated control of fire blight with antagonists and oxytetracycline. Acta Hortic. 793:383-390

31. Temple, T. N., Stockwell, V. O., Loper, J. E., and Johnson, K. B. 2004. Bioavailability of iron to Pseudomonas fluorescens strain A506 on flowers of pear and apple. Phytopathology 94:1286-1294.

32. Thomson, S. V. 1986. The role of the stigma in fire blight infections. Phytopathology 76:476482.

33. Thomson, S. V. 2000. Epidemiology of fire blight. Pages 9-36 in: Fire Blight: The Disease and its Causative Agent, Erwinia amylovora. J. L. Vanneste, ed. CABI Publishing, Oxon, UK.

34. Vanneste, J. L., Cornish, D. A., Yu, J., and Voyle, M. D. 2002. P10c: A new biological control agent for control of fire blight which can be sprayed or distributed using honey bees. Acta Hortic. 590:231-236.

35. Wilson, M., and Lindow, S. E. 1993. Interactions between the biological control agent Pseudomonas fluorescens A506 and Erwinia amylovora in pear blossoms. Phytopathology 83:117-123.

36. Wilson, M., Sigee, D. C., and Epton, H. A. S. 1990. Erwinia amylovora infection of hawthorn blossom: III. The nectary. J. Phytopathol. 128:62-74.

37. Zhao, Y. F., Blumer, S. E., and Sundin, G. W. 2005. Identification of Erwinia amylovora genes induced during infection of immature pear tissue. J. Bacteriol. 187:8088-8103. 